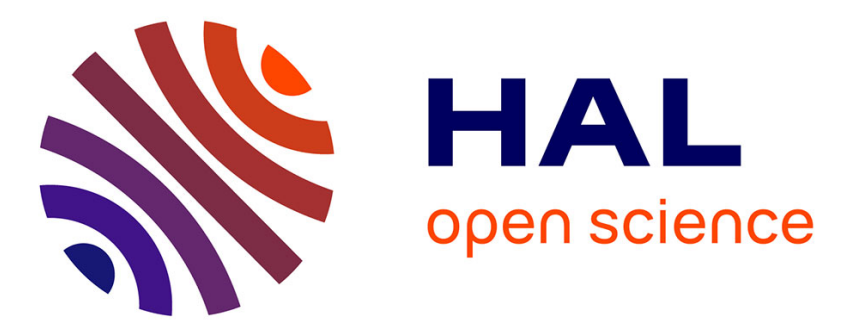

\title{
Anti-angiogenic effects of dietary isothiocyanates; mechanisms of action and implications for human health
}

Breeze E. Cavell, Sharifah S. Syed Alwi, Alison Donlevy, Graham Packham

\section{To cite this version:}

Breeze E. Cavell, Sharifah S. Syed Alwi, Alison Donlevy, Graham Packham. Anti-angiogenic effects of dietary isothiocyanates; mechanisms of action and implications for human health. Biochemical Pharmacology, 2010, 81 (3), pp.327. 10.1016/j.bcp.2010.10.005 . hal-00654981

\section{HAL Id: hal-00654981 \\ https://hal.science/hal-00654981}

Submitted on 24 Dec 2011

HAL is a multi-disciplinary open access archive for the deposit and dissemination of scientific research documents, whether they are published or not. The documents may come from teaching and research institutions in France or abroad, or from public or private research centers.
L'archive ouverte pluridisciplinaire HAL, est destinée au dépôt et à la diffusion de documents scientifiques de niveau recherche, publiés ou non, émanant des établissements d'enseignement et de recherche français ou étrangers, des laboratoires publics ou privés. 


\section{Accepted Manuscript}

Title: Anti-angiogenic effects of dietary isothiocyanates; mechanisms of action and implications for human health

Authors: Breeze E. Cavell, Sharifah S. Syed Alwi, Alison Donlevy, Graham Packham

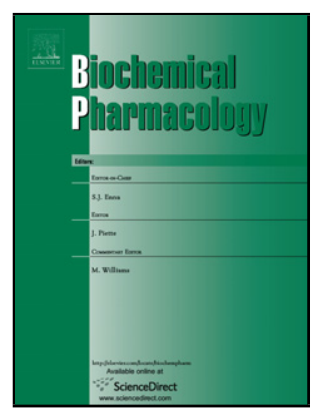

PII:

S0006-2952(10)00761-6

DOI:

doi:10.1016/j.bcp.2010.10.005

Reference:

BCP 10737

To appear in: $\quad B C P$

Received date: $\quad 10-8-2010$

Revised date: $\quad 7-10-2010$

Accepted date: $\quad 8-10-2010$

Please cite this article as: Cavell BE, Alwi SSS, Donlevy A, Packham G, Antiangiogenic effects of dietary isothiocyanates; mechanisms of action and implications for human health, Biochemical Pharmacology (2010), doi:10.1016/j.bcp.2010.10.005

This is a PDF file of an unedited manuscript that has been accepted for publication. As a service to our customers we are providing this early version of the manuscript. The manuscript will undergo copyediting, typesetting, and review of the resulting proof before it is published in its final form. Please note that during the production process errors may be discovered which could affect the content, and all legal disclaimers that apply to the journal pertain. 
Isothiocyanates and angiogenesis

\section{Anti-angiogenic effects of dietary isothiocyanates; mechanisms of action and implications for human health}

Breeze E Cavell, Sharifah S Syed Alwi, Alison Donlevy, Graham Packham

Southampton Cancer Research UK Centre, Cancer Sciences Division, University of Southampton School of Medicine, UK. 
Running title; Isothiocyanates and angiogenesis

Address for correspondence; Professor Graham Packham, Cancer Research UK Centre, Somers Cancer Research Building (MP824), Cancer Sciences Division, University of Southampton School of Medicine, Southampton General Hospital, Tremona Road, Southampton, SO16 6YD, UK. Tel [44](0)23 8079 6184; Fax [44](0)23 8079 5152; Email G.K.Packham@soton.ac.uk

Document statistics

Words; 5233

Figures; 4

References;101

Abbreviations;

4E-BP1, translation factor 4E binding protein 1; AITC, allyl isothiocyanate; Ang2, angiopoietin 2; AP1, activator protein 1; bFGF, basic fibroblast-like growth factor; BITC, benzyl isothiocyanate; BNIP3, BCL2/adenovirus E1B 19kDa interacting protein; CAIX, carbonic anhydrase IX; CBP, CREB binding protein; elF4A, eukaryotic translation initiation factor $4 \mathrm{~A}$; elF4E, eukaryotic translation initiation factor $4 \mathrm{E}$; elF4F, eukaryotic translation initiation factor 4F; elF4G, eukaryotic translation initiation factor 4G ; FIH, factor inhibiting HIF1; GLUT1, glucose transporter type 1 ; GSH, glutathione; GST, glutathione-S-transferases; HDAC, histone deacetylases; HIF, hypoxia inducible factor; HRE, hypoxia-response elements; HUVEC, human umbilical vein endothelial cells; IL8, interleukin 8; ITC, isothiocyanate; JNK, Jun Nterminal kinase; Keap1, kelch-like ECH-associated protein 1; mTOR, mammalian target of rapamycin; NAC, $N$-acetylcysteine; NF- $\kappa B$, nuclear factor $\kappa B$; PHD, prolyl hydoxylases; PEITC, phenethyl isothiocyanate; PGK1, phosphoglycerate kinase 1; ROS, reactive oxygen species; SFN, sulforaphane ; TGF $\beta$, transforming growth factor $\beta$; VEGF, vascular endothelial growth factor; UTR, untranslated region; VHL, von Hippel-Landau protein 
Isothiocyanates and angiogenesis

\begin{abstract}
Isothiocyanates (ITCs) are electrophilic compounds derived from plants and are thought to play a major role in the potential chemopreventive effects associated with high intake of cruciferous vegetables. ITCs are also being evaluated for chemotherapeutic activity in early phase clinical trials. In addition to their effects on carcinogen metabolism and cancer cell survival and proliferation, ITCs have been shown to effectively interfere with angiogenesis in vitro and in vivo. Angiogenesis is the development of a new blood supply from existing vasculature and is required for tumours to develop beyond a small size limit determined by the diffusion limit for oxygen. Inhibition of angiogenesis may play a key role in the potential chemopreventive/chemotherapeutic activity of ITCs. In this review we highlight recent data demonstrating that ITCs have anti-angiogenic activity and identify potential molecular targets for these effects, including hypoxia-inducible factor (HIF), nuclear factor $\kappa \mathrm{B}(\mathrm{NF}-\kappa \mathrm{B})$, activator protein 1 (AP1) and tubulin. We also discuss these findings in light of the potential chemopreventive/chemotherapeutic effects of ITCs.
\end{abstract}

Key words; isothiocyanates; angiogenesis; hypoxia inducible factor; nuclear factor $\kappa \mathrm{B}$; tubulin 
Isothiocyanates and angiogenesis

\section{Introduction}

Isothiocyantes (ITCs) are low molecular weight organic compounds with the general formula R-NCS. They are derived from plants where they are stored as glucosinolate precursors. Tissue damage due to chopping or mastication activates the plant enzyme myrosinase which hydrolyses the glucosinolate resulting in the formation of ITCs (Fig. 1). Variation in the R-group of glucosinolates gives rise to various ITCs which may exert distinct biological activities. Cruciferous vegetables are a particularly abundant source of ITCs and these compounds are thought to play a major role in the potential chemopreventive effects of diets rich in cruciferous vegetables. The anti-cancer activity of non-dietary administration of ITCs is also being evaluated in several early phase clinical trials.

The mechanisms by which ITCs exert their potential chemopreventive effects are likely to be multifactorial and are summarized in Table 1. For recent reviews please see [1-3]. The ability of ITCs to reduce carcinogen-induced tumourigenesis in experimental animals is relatively well understood; ITCs increase carcinogen detoxification via inhibition of carcinogen-activating phase I enzymes and induction of carcinogen-detoxifying phase II enzymes. However, more recently it has become clear that ITCs can also exert "direct" anti-cancer effects against established cancer cells in systems where carcinogens are not thought to play a role. For example, ITCs decrease in vivo growth of xenograft, as well as radiation- or genetically-induced, tumours. ITCs induce cell cycle arrest and cell death in cancer cells in vitro, and interfere with cancer cell invasion and metastasis (for recent reviews, see [1, 3, 4]). Importantly, normal cells appear to be relatively resistant to these effects. ITCs have recently been shown also to interfere with angiogenesis, a key process required for the progression of early tumours and a well established target for both chemopreventive and chemotherapeutic agents. In this review, we discuss the evidence that ITCs can act as anti-angiogenic agents. We also identify potential molecular mechanisms that mediate these effects and discuss these findings in light of the potential chemopreventive/chemotherapeutic effects of ITCs.

\section{Chemistry and metabolism of ITCs}


The central carbon atom of the -NCS group is highly electrophilic and it is this reactivity with cellular nucleophiles that underpins the molecular effects and the metabolism of ITCs. Differences in the side-chain may modify the reactivity of ITCs by influencing electophilicity of the -NCS group, accessibility to nucleophilic centres and lipophilicity.

Following absorption, ITCs are predominantly metabolised by the mercapturic acid pathway. Conjugation of ITCs to glutathione (GSH) results in the formation of an ITC-GSH conjugate in a reaction catalysed by GST enzymes. ITC-GSH is subsequently converted to the cysteinylglycine conjugate by the action of $\gamma$ glutamyltranspeptidase which is then converted to the cysteine conjugate by the action of cysteinylglycinase. Finally, the ITC-cysteine conjugates are converted to $\mathrm{N}$ acetylcysteine (NAC) conjugates by the action of $\mathrm{N}$-acetyltransferase and excreted in the urine. The urinary excretion of ITC conjugates has been used to study the bioavailability of ITC, which appears to be quite high [5]. For example, when benzyl isothiocyanate (BITC) was administered orally to humans, $54 \%$ of the dose was recovered in the urine as BITC-NAC [6]. However, availability of ITCs from specific foods is influenced by preparation (i.e., raw versus cooked) and eating habit (i.e. extent of chewing) $[7,8]$.

Interestingly, polymorphisms within the genes encoding GST enzymes may influence the metabolism of specific ITCs and their potential chemopreventive effects. For example, Brennan et al. demonstrated that the protective effect of high cruciferous vegetable intake on lung cancer risk was greatest in those individuals with GSTM1 and/or GSTT1 null genotypes [9]. One possible explanation for these findings is that the presence of GST null genotypes decreases ITC metabolism and hence increases exposure. However, studies have shown that the GSTM1 null genotype is associated with a greater rate of excretion of SFN metabolites [10] and other epidemiological studies have concluded that GSTM1 positive individuals gain greater cancer protection from cruciferous vegetable ingestion than do GSTM1 null individuals [11]. Since the effect of GST polymorphisms may be influenced by the predominant ITC consumed, there are likely to be complex interactions between ITC ingestion, genomics, and potential chemopreventive benefits. 
Isothiocyanates and angiogenesis

A particularly interesting feature of the pharmacokinetics of ITCs is their rapid and profound intracellular accumulation (Fig. 2). As discussed above, ITCs are rapidly conjugated to GSH, the most abundant cellular thiol (typically present at concentrations of $1-10 \mathrm{mM}$ ) via the action of GST enzymes following diffusion into cells. The resulting intracellular dithiocarbamates are exported from the cell by transporters such as multi-drug resistance protein-1 and p-glycoprotein-1 [12]. However, extracellular hydrolysis of GSH-ITC conjugates can also release free ITCs which are able to re-enter the cell where they are then able to react again with $\mathrm{GSH}$. The net effect of this is a depletion of intracellular GSH and a large accumulation (100-200 fold over the extracellular ITC concentration) of intracellular ITCs. For example, treatment of Hepa 1c1c7 murine hepatoma cells with $100 \mu \mathrm{M} \mathrm{SFN}$ for 30 minutes resulted in total levels of intracellular SFN/SFN conjugates of $6.4 \mathrm{mM}, 95 \%$ of which was SFN-GSH [13].

The consequences of this complex interplay between ITC conjugation, metabolism and efflux/uptake of ITCs are three-fold. First, GSH is a major antioxidant and its depletion leads to an increase in intracellular reactive oxygen species (ROS) [14]. Second, conjugates of ITCs generated via mercapturic acid pathway can themselves exert effects, for example, by the inhibition of histone deacetylases (HDACs) [15]. Finally, ITCs can react directly with other extracellular and intracellular targets. ITCs readily conjugate to protein cysteinyl thiols, whereas binding to DNA or RNA is not observed [16, 17]. For example, in phenethyl isothiocyante (PEITC)-treated A549 cells, intracellular levels of PEITC-GSH conjugates reached a maximum at 30 minutes post treatment and dropped rapidly thereafter. By contrast, PEITC-protein content gradually increased, accounting for $87 \%$ of total cellular content by 4 hours. Interestingly, sulforaphane (SFN)-protein conjugates accounted for only $12 \%$ of total SFN uptake at the same time point. Protein thiocarbamoylation can be a powerful modulator of protein function and is, for example, considered to play a key role in the induction of phase II carcinogen-metabolising enzymes by ITCs via induction of the Nrf2 transcription factor [18, 19]. PEITC appears to bind to proteins more readily than SFN, perhaps accounting for its more potent apoptosis promoting activity [Mi 
2007]. All three of these effects - increased ROS, direct action of metabolites and protein conjugation - are thought to contribute to anti-cancer effects of ITCs.

\section{Tumour angiogenesis}

Angiogenesis is the development of a new blood supply from an existing vasculature. The acquisition of angiogenic potential is considered a hallmark of malignant cells since it is required for tumours to grow beyond a small size $(\sim 1-2 \mathrm{~mm}$ in diameter), and to invade surrounding tissues and metastasise. Angiogenesis increases with cancer progression and has been linked to poor prognosis in a range of malignancies. Increased angiogenesis has also been observed in preneoplastic conditions [20], indicating that it plays a key role early in the process of carcinogenesis. Angiogenesis is a validated target for the development of both chemotherapeutic and chemopreventive agents.

Tumour angiogenesis is mediated by a complex interplay between malignant cells and endothelial cells, as well as stromal and immune cells and the extracellular matrix [21]. Cancer cells can produce a range of pro-angiogenic factors, including basic fibroblast-like growth factor (bFGF), vascular endothelial growth factor (VEGF), angiopoietin 2 (Ang2), interleukin 8 (IL8) and transforming growth factor $\beta$ (TGF $\beta$ ). These factors act to promote the survival, recruitment and proliferation of endothelial cells, resulting in the formation of new blood vessels. It is widely accepted that an "angiogenic switch" is activated when these pro-angiogenic factors outweigh the production of natural, anti-angiogenic factors (such as angiostatin, endostatin and thrombospondins). This switch can be triggered by immune/inflammatory responses, growth factors and genetic changes within cancer cells. However, hypoxia itself (i.e., low oxygen concentrations) is a major inducer of angiogenesis. Thus, cells which are located at a distance greater than the diffusion limit for $\mathrm{O}_{2}(\sim 100 \mu \mathrm{m})$ are hypoxic, leading to induction of pro-angiogenic factors and activation of the angiogenic switch.

\section{Anti-angiogenic effects of isothiocyanates}


Isothiocyanates and angiogenesis

Various studies have shown that ITCs can interfere with angiogenesis in vitro and in vivo. Cultured human umbilical vein endothelial cells (HUVECs) are a well studied in vitro system to investigate modulation of angiogenesis and SFN has been shown to suppress both the proliferation and the matrigel-dependent tube forming ability of these cells [22]. Tube forming assays measure a complex series of events involving changes in endothelial cell morphology and migration, leading to the formation of a complex interconnecting network of capillary tubes with identifiable lumens (branching morphogenesis). Similar results have been shown for SFN using the immortalised human microvascular endothelial cell line, HMEC-1, and SFN was additionally demonstrated to decrease endothelial cell migration in a "wound healing assay" in these cells [23]. Similarly, PEITC has been shown to suppress HUVEC survival, migration (modified Boyden chamber) and tube formation [24] and allyl isothiocyanate (AITC) suppressed HUVEC proliferation, migration, invasion and tube formation [25]. In cultured bovine aortic endothelial cells, SFN-induced inhibition of proliferation was associated with G2/M phase cell cycle arrest [26].

In ex vivo tissue culture models, SFN caused a dose dependent reduction of microcapillary density in a placental vessel fragment outgrowth assay [23] and PEITC decreased vascular density in chicken egg chorioallantoic membrane assays [24]. AITC also decreased outgrowth of microvessels from rat aortic rings [27]. Intravenous administration of SFN decreased in vivo angiogenesis in VEGFimpregnated matrigel plugs [26] and intraperitoneal administration of AITC decreased in vivo capillary formation using the mouse B16F-10 melanoma model [27]. In these in vivo studies, the anti-angiogenic activity of ITCs was associated with reduced production of pro-angiogenic factors in vivo, including VEGF, nitric oxide and tumour necrosis factor $\alpha[25,27]$. SFN has been shown to reduce blood vessel density in MIA-PaCa2 xenografts in vivo [28]. Thus, various ITCs have been shown to exert anti-angiogenic activity in both in vitro and in vivo assays.

\section{Modulation of hypoxia inducible factor activity}


Hypoxia inducible factors (HIF) may be key targets mediating the anti-angiogenic activity of ITCs. HIFs comprise a small family of dimeric basic helix-loop-helix transcription factors that play a central role in angiogenesis, linking hypoxia to the regulation of pro-angiogenic gene expression (e.g., VEGF), as well as regulators of cell survival (e.g. BCL2/adenovirus E1B 19kDa interacting protein 3 [BNIP3]), metabolism (e.g. glucose transporter type 1 [GLUT1], phosphoglycerate kinase 1 [PGK1]) and pH control (carbonic anhydrase IX [CAIX]) [29, 30]. The HIF family comprises three dimeric complexes, HIF1, 2 and 3, each of which comprises a hypoxia inducible alpha subunit (HIF1 $\alpha, \mathrm{HIF} 2 \alpha$ or HIF3 $\alpha$ ) complexed with the constitutively expressed HIF1 $\beta$ subunit. The HIF1 and HIF2 factors are well characterised positive regulators of angiogenesis, whereas the function of HIF3 is less well understood.

The expression of HIF $\alpha$ subunits is tightly regulated via ubiquitylation and proteolysis $[29,30]$. In normoxic conditions, HIF $\alpha$ subunits are hydroxylated on conserved proline residues by the action of oxygen sensitive prolyl hydoxylases (PHD) (Fig. 3). This triggers binding to the von Hippel-Landau (VHL) protein, an ubiquitin E3 ligase, and subsequent ubiquitylation and degradation via the proteasome. In hypoxic conditions, PHD activity is inhibited and HIF $\alpha$-subunits are stabilized. Once HIF $\alpha$ subunits accumulate, they associate with HIF1 $\beta$ and activate transcription by binding to hypoxia response elements in the promoters of target genes. The transactivating activity of HIF1 $\alpha$ is also regulated by hypoxia. In normoxia, factor inhibiting HIF1 $(\mathrm{FIH})$ hydroxylates asparagine residues within the $\mathrm{C}$-terminal transactivation domain of HIF1 $\alpha$ thereby displacing p300/CREB binding protein (CBP) coactivator proteins. Similar to PHD enzymes, $\mathrm{FIH}$ is oxygen sensitive; asparagine hydroxylation is decreased in hypoxia enabling p300/CBP binding and enhancement of transcriptional activation.

Several studies have demonstrated that ITCs modulate the expression and function of HIF, in both malignant and endothelial cells. Studies from our own laboratory have shown that PEITC effectively interferes with hypoxia-induced HIF transcriptional activity and the induction of the endogenous HIF target genes VEGF-A, BNIP3, CAIX and GLUT1 in human MCF7 breast cancer cells [31]. Similarly, SFN decreases 
VEGF production in response to hypoxia in human Tca8113 tongue squamous cell carcinoma cells and human DU145 prostate cancer cells [32]. In these studies, inhibitory effects of the ITCs appeared to be due to decreased translation of $\mathrm{HIF} 1 \alpha / \mathrm{HIF} 2 \alpha$, rather than decreased transcription or enhanced protein turnover [31, 32]. For example, inhibition of HIF activity in MCF7 cells was not associated with changes in HIF1 $\alpha$ RNA levels. PEITC also suppressed the constitutive expression of HIF target genes in normoxia in RCC4 renal carcinoma cells, which are deficient in VHL and therefore unable to degrade HIF $\alpha$ proteins via the canonical VHL pathway. Indeed, using ${ }^{35} \mathrm{~S}$-metabolic labelling in MCF7 cells we have now directly demonstrated that PEITC suppresses HIF1 $\alpha$ translation (BEC and GP, unpublished data). SFN also induced downregulation of HIF1 $\alpha$ expression and VEGF production in HMEC1 cells [23]. However, in these cells, decreased HIF1 $\alpha$ protein expression was associated with reduced $H I F 1 \alpha$ RNA levels suggesting a predominant role for transcriptional modulation.

A key question is how ITCs decrease HIF1 $\alpha$ translation [31, 32]. PEITC has previously been shown to modulate the phosphorylation and expression of the protein translation factor 4E binding protein 1 (4E-BP1) [33]. 4E-BP1 is a key negative regulator of the translation promoting complex eukaryotic translation initiation factor $4 \mathrm{~F}$ (elF4F) which comprises three subunits, the scaffold protein eukaryotic translation initiation factor $4 \mathrm{G}$ (elF4G), the RNA-helicase eukaryotic translation initiation factor $4 \mathrm{~A}$ (elF4A) and the cap-binding protein eukaryotic translation initiation factor 4E (elF4E) [34]. The function of elF4F is tightly regulated by $4 \mathrm{E}-\mathrm{BP}$ family proteins, of which $4 \mathrm{E}-\mathrm{BP} 1$ is the most prominent. $4 \mathrm{E}-\mathrm{BP} 1$ competes with elF4G for an overlapping binding site on elF4E in a phosphorylation-dependent manner. Dephosphorylation of 4E-BP1 increases affinity for elF4E and therefore inhibits elF4F. PEITC decreased 4E-BP1 expression and phosphorylation on multiple sites ( $\mathrm{Thr}^{37} / \mathrm{Thr}^{46}, \mathrm{Thr}^{70}$ and $\mathrm{Ser}^{65}$ ) in various cancer cell lines, including HCT116 (colorectal), PC3 (prostate) and MCF7 (breast) cells [31, 33], and decreased CAP-dependent RNA translation. Notably, the translation of RNAs with highly structured 5' untranslated regions (UTRs) is particularly dependent on the activity of elF4F [35] and would therefore be expected to be particularly sensitive to 
4E-BP1 levels/phosphorylation. Consistent with this, PEITC preferably inhibited CAP-dependent translation of RNAs with a high level of secondary structure [33].

Interestingly, the 5' UTR of the HIF1 $\alpha$ mRNA is highly structured, suggesting it may be particularly sensitive to translation inhibition by ITCs. This sensitivity is apparent in cells treated with the immunosuppressant rapamycin, an inhibitor of the mammalian target of rapamycin (mTOR)-containing mTORC1 complex, a major regulator of 4E-BP1 phosphorylation. Thus, mTORC1 inhibition leads to 4E-BP1 dephosphorylation and decreased translation of RNAs with highly structured 5'UTRs, including HIF1 $\alpha$ [36]. However, effects of PEITC on translation are likely to be complex. For example, we demonstrated that PEITC also decreased expression of HIF2 $\alpha$ protein in MCF7 cells [31], although HIF2 $\alpha$ RNA does not have a highly structured 5'-UTR and is not effectively repressed by rapamycin [36]. Thus, ITCs may affect global protein production via inhibition of CAP-dependent translation, although some RNAs with highly structured 5'-UTRs might be particularly susceptible. Importantly, overexpression of elF4E protected HCT116 from PEITCinduced growth inhibition, indicating that translation repression contributes to the growth inhibitory effects of PEITC [33]. However, since these experiments were performed in normoxia, modulation of HIF activity is unlikely to be important for these effects. Enhanced translation of cell survival (Bcl- $\mathrm{X}_{\mathrm{L}}$ ) and proliferation (cyclin $\mathrm{D} 1$ ) proteins, known to be induced following elF4E overexpression in other systems, might contribute to protection from PEITC-induced growth inhibition. Taken together, PEITC (and presumably other ITCs) may exert a general inhibitory effect on translation. However, HIF1 $\alpha$ is highly sensitive to decreased translational efficiency and decreased HIF1 $\alpha$ translation is likely to be an important mechanism mediating anti-angiogenic effects of ITCs.

\section{HIF-independent control of angiogenesis}

There are also HIF-independent pathways of tumour angiogenesis (Fig. 4) [37]. For example, knock-down of HIF1 $\alpha$ does not prevent angiogenesis or VEGF expression in xenograft models of colon cancer [38]. The transcription factors nuclear factor kappB (NF-kB), activator protein-1 (AP1) and MYC activate expression of pro- 
angiogenic factors, such as VEGF and/or IL-8 [37], and inhibition of these factors by ITCs may also contribute to anti-angiogenic effects. RAS oncoproteins appear to act as master regulators of these HIF-independent pathways [37]. Given the importance of these HIF-independent pathways, it is important to consider whether their modulation might also contribute to anti-angiogenic effects of ITCs.

The NF-kB family of dimeric transcription factors are widely expressed and play a key role in controlling the onset and the resolution of inflammation as well as stress responses, intercellular signalling, cellular proliferation, angiogenesis and apoptosis [39]. In most cells, NF-kB proteins are complexed with inhibitor proteins ( $\mathrm{k} B$ proteins) in an inactive form in the cytoplasm. Various stimulators cause the activation of a multiple-protein kinase complex (IKK) which phosphorylates $I_{\kappa} B$ proteins targeting them for degradation and leading to the nuclear translocation and activation of NF-kB. NF- $\mathrm{kB}$ is thought to play a key HIF-independent role in tumour angiogenesis, via induction of IL8 and VEGF. Indeed, increased production of ROS due to HIF inhibition activates NF-kB and heightens its role in angiogenesis [38]. Also, inactivation of PHDs in hypoxia can activate NF-kB following decreased hydroxylation of IKK $\beta[40]$.

The first reported study of ITC-mediated NF-kB inhibition demonstrated that SFN decreased NF-KB DNA binding activity and target gene expression in lipopolysaccharide treated RAW264.7 mouse macrophages [41]. Since then ITCs have been shown to decrease NF-kB activity in various human cancer cell lines, including HT-29 (colorectal), BxPC3, MIA-PaCa-2 (both pancreatic cancer), PC3 (prostate cancer) and T24 (bladder cancer) [28, 42-45]. Various mechanisms may contribute to modulation of NF-kB activity. For example, Heiss et al. demonstrated that SFN did not block $\kappa_{\kappa} B \alpha / \beta$ degradation or nuclear import of the NF-kB subunits p50 (NF-kB1) and p65 (RelA), but could directly interfere with NF-kB DNA binding in vitro [41]. By contrast, others have shown that ITCs reduce phosphorylation and increase expression of $\mathrm{I}_{\mathrm{KB} \alpha}[42-44,46]$. SFN and PEITC inhibited IKK $\beta$-mediated phosphorylation of $I_{\kappa} B \alpha$ in an in vitro assay, suggesting that IKK $\beta$ may be a direct target for modulation by ITCs [44]. 
As discussed above, protein thiocarbamoylation is thought to play an important role in the anticancer effects of ITCs [47]. For example, direct covalent modification of the negative regulator kelch-like ECH-associated protein 1 (Keap1) by SFN is thought to contribute to activation of Nrf2, required for activation of phase II carcinogeninactivating enzymes and protection from carcinogen-induced cancer [18, 19, 48, 49]. Interestingly, a number of reactive chemical compounds have been shown to inhibit NF-kB activity via direct covalent modification of NF-kB signalling pathway components. For example, the DNA binding domains of the p50 and p65 NF-kB subunits contain redox-regulated cysteine residues (Cys ${ }^{62}$ and Cys ${ }^{38}$, respectively) that have been shown to be covalently modified by andrographolide and picroliv, respectively, thereby preventing DNA binding [50,51]. Also, IKK $\beta$ contains a redox regulated cysteine residue (Cys ${ }^{179}$ ) that is essential for activity [52], and is modulated by other agents such as curcumin and butein (3,4,2,4-tetrahydroxychalcone) [53, 54]. Thus, these cysteine residues are candidate sites for thiocarbamoylation by ITCs, although direct evidence for covalent binding to NF-kB subunits by this class of molecule is lacking. Very recent studies have demonstrated that, in addition to Nrf2, Keap1 can function as a ubiquitin E3 ligase for IKK $\beta$ and thereby downregulate NF$\kappa \mathrm{B}$ activity [55]. However, it is not known whether modulation of Keap1 by ITCs per se leads to increased expression/activity of IKK $\beta$.

The AP1 transcription factor is also important for angiogenesis. AP1 comprises a dimer of Jun/Fos family proteins that modulates specific gene expression in response to a wide range of stimuli, including growth factors, stress, infection and oncogenic stimuli $[56,57]$. The AP1 activating kinase Jun N-terminal kinase (JNK) is activated downstream of K-RAS in hypoxic cells, and JunB may be required for NF$\kappa B$ mediated induction of VEGF [58]. Inhibition of AP1 by ITCs has been observed in cancer lines, including HT29 cells, and in the skin in vivo following UVB-irradiation [59-61]. In vitro studies have shown that SFN-inhibition of AP1 DNA binding is dependent on Cys ${ }^{154}$ of $\mathrm{c}-\mathrm{Fos}$ and $\mathrm{Cys}^{272}$ of C-Jun, suggesting that these may be sites of direct covalent modification by ITCs [61]. However, the effects of ITCs on AP1 are complex and other studies have reported induction of AP1 transcriptional activity by ITCs in a range of cell lines $[59,60,62,63]$. 
Isothiocyanates and angiogenesis

The MYC oncoprotein also plays a key role in angiogenesis, by upregulation of

VEGF and downmodulation of thrombospondins. MYC expression is induced in hypoxic cells via activation of $\mathrm{PI} 3 \mathrm{~K} \rightarrow \mathrm{Rho} \rightarrow \mathrm{ROCK}$ signalling. ITCs downmodulate MYC expression in HMEC1 cells [23] but the mechanism for this remains unknown.

\section{Covalent modification of tubulin}

Only a small number of direct targets for ITC-mediated thiocarbamoylation have been identified to date and the potential impact on NF-KB and AP1 have been discussed above. However, the best characterized target are tubulins. Tubulins are a family of globular proteins which assemble to form microtubules. Microtubules are essential for chromosome segregation during mitosis and inhibition of microtubule function may therefore be one mechanism leading to ITC-induced mitotic cell cycle arrest (including in endothelial cells [26]). However, tubulins also play important roles in angiogenesis in addition to proliferation of endothelial cells since they are also required for morphogenesis and migration.

The ability of SFN to inhibit tubulin polymerisation in vitro and in intact cells had been recognised for some time $[64,65]$. However, radiolabelling experiments have now demonstrated that PEITC and SFN directly conjugate to both $\alpha$ - and $\beta$-tubulin isoforms [66]. Multiple molecules of ITCs interact with individual tubulin molecules, at least in vitro, and BITC has been shown to conjugate to $\mathrm{Cys}^{347}$ of $\alpha$-tubulin in intact cells. BITC and PEITC effectively inhibit tubulin polymerisation in vitro and disrupt microtubules in intact cells, whereas SFN exerts more modest effects [66]. More recently it has been shown that BITC and PEITC, but not SFN, also promote the proteasome-dependent degradation of $\alpha / \beta$ tubulin in HeLa cells and non-small cell lung cancer-derived H460 cells [67] and PC3 and DU145 prostate cancer cells [68]. Pharmacological anti-tubulin agents can exert powerful antiangiogenic effects, so inhibition of tubulin could also contribute to inhibition of angiogenesis by ITCs. Interestingly, microtubule agents also inhibit the translation of HIF1 $\alpha$ RNA through a poorly defined mechanism [69] and thus might also play a role in inhibition of $\mathrm{HIF} 1 \alpha$ protein expression. 


\section{A role for ROS and ITC metabolites?}

In addition to protein thiocarbamoylation, the anti-cancer activities of ITCs are thought to involve increased production of ROS and effects of ITC metabolites. Although their effects are complex, ROS are generally considered to promote angiogenesis so it is unlikely that an initial production of ROS in ITC-treated cells would contribute to suppression of angiogenesis. However, it is important to bear in mind that although initially acting as pro-oxidants, ITCs can also act as indirect antioxidants. ITCs can lead to activation of Nrf2, a master inducer of anti-oxidant gene expression. Thus, following prolonged exposure to ITCs, raised intracellular antioxidant status may contribute to reduced angiogenesis. Metabolites of ITCs can act as inhibitors of HDACs [70]. HDACs and their counteracting partners, histone acetyltransferases, control the acetylation status of not just histones, but also a wide range of other cellular proteins, including HIF1. HIF1 transcriptional activity is inhibited by acetylation of HIF1 $\alpha$ suggesting that inhibition of HDACs via ITCmetabolites might also impact on HIF activity. Indeed, pharmacological HDAC inhibitors have anti-angiogenic activity [71]. However, there is no evidence that HIF acetylation is modulated in ITC-treated cells.

\section{Relevance for chemoprevention and chemotherapy}

It is important to consider these results linking ITCs to inhibition of angiogenesis, as well as their effects on other cancer associated pathways (Table 1), in the context of their potential chemopreventive/chemotherapeutic activity. Cruciferous vegetables are a rich dietary source of ITCs and although recent prospective studies have suggested that the relationship between cancer risk and cruciferous vegetable intake is more complex than originally thought, there remains intense interest in the potential chemopreventive activities of ITCs. Given the key role of angiogenesis for the progression of early tumours (and potentially also pre-neoplastic lesions), inhibition of angiogenesis may play an important role in the potential chemopreventive effects of these compounds. Notably, "classical" anti-angiogenic 
drugs, such as the anti-VEGF antibody Bevacizumab typically extend patient survival by only a relatively short period. These limited clinical responses are perhaps not surprising given that these agents selectively target just one of many factors that act in concert to modulate angiogenesis. In this regard, the multifunctional effects of ITCs may be beneficial in providing an effective block to angiogenic activity.

The critical question is whether normal dietary intake of cruciferous vegetables might be adequate to deliver sufficient concentrations of ITCs to inhibit angiogenesis (or, indeed, other cancer promoting pathways that have been shown to be suppressed by ITCs in vitro). One approach to address this question is to compare the levels of ITCs that appear in the blood following ingestion of glucosinolate-rich foods with the concentrations required to exert effects in vitro (see Table 2 for a summary of molecular effects of ITCs potentially linked to anti-angiogenic activity with an indication of effective concentrations). In general, ITC concentrations required for in vitro modulation of angiogenesis, or to exert effects on molecular regulators such as $\mathrm{HIF}$, are in the order of 1-20 $\mu \mathrm{M}$, and only few studies report significant effects at concentrations $<1 \mu \mathrm{M}[23,24]$. Pharmacokinetic studies have demonstrated that ITCs are detectable in the blood following ingestion of cruciferous vegetables, but these levels would appear to fall short of those required for modulation of angiogenesis pathways. For example, in two studies, the mean peak plasma concentrations of PEITC following ingestion of 80 or $100 \mathrm{~g}$ of watercress were 297 and $928 \mathrm{nM}$, respectively [72, 73]. The mean peak plasma concentration of SFN following ingestion of $150 \mathrm{ml}$ of broccoli "soup" equivalent to $100 \mathrm{~g}$ of broccoli was $\sim 650 \mathrm{nM}$ [74]. However, these comparisons are complicated by the presence of ITCmetabolites, some of which may be active. For example, whereas the peak plasma concentration of SFN following ingestion of $150 \mathrm{ml}$ of broccoli "soup" was only 650 $\mathrm{nM}$, the total amount of SFN plus SFN metabolites (i.e. SFN-GSH, SFN-cysteineglycine, SFN-N-acetylcysteine and SFN-cysteine) was $\sim 2 \mu \mathrm{M}$ and this rose to $\sim 7 \mu \mathrm{M}$ following ingestion of an equivalent amount of "super-broccoli", bred to provide higher levels of ITCs [10, 74]. Moreover, even partial inhibition of multiple molecular regulators that may be achieved with relatively low levels of ITCs may cooperate to provide effective suppression of angiogenesis. 
Another limitation of measuring plasma ITC levels is that it is the intracellular levels which are presumably of most importance. Intracellular concentrations of ITCs may vary from cell type to cell type due a complex interplay between metabolism, GSHconjugation and transport (Fig. 2). Therefore, an alternate approach to assess the bioavailability of dietary ITCs is to measure effects on intracellular biomarkers in circulating blood cells. Rowland and colleagues have demonstrated reduced levels of basal and hydrogen peroxide-induced DNA damage in peripheral blood lymphocytes, presumably due to Nrf2-dependent increased antioxidant gene expression, following daily intake of $85 \mathrm{~g}$ of watercress for 8 weeks [75]. Our own pilot work has shown that ingestion of watercress $(80 \mathrm{~g})$ appears to be sufficient to cause a transient decrease in 4E-BP1 phosphorylation [73] mirroring effects seen in vitro in cancer cells $[31,33]$. Moreover, ingestion of SFN-enriched broccoli sprouts is associated with inhibition of HDAC activity and accumulation of acetylated histone [76] consistent with the in vitro HDAC-inhibitory activity of ITC metabolites. Thus, although falling well short of proof that dietary intake of ITCs has anti-cancer effects, these experiments provide encouraging data that the bioavailability of ITCs is sufficient to modulate pathways which have been associated with anti-cancer effects of ITCs in in vitro studies. Further studies are clearly required but molecular biomarker analysis may be a powerful approach to address the in vivo effects of dietary intake of ITCs, including effects on angiogenesis.

The findings described here are also relevant in the context of clinical trials designed to explore the potential chemopreventive/chemotherapeutic effects of ITCs. We identified 4 clinical trials evaluating either pure PEITC or SFN-enriched broccoli sprout extract in cancer clinical trials (http://www.cancer.gov/clinicaltrials). PEITC induces apoptosis of primary chronic lymphocytic leukaemia cells in vitro [77] and a planned phase I trial (NCT00968461) will determine the maximum tolerated dose of oral PEITC in patients with previously treated lymphoproliferative disorders. A randomized and placebo-controlled phase II trial (NCT00691132) will assess the effects of oral PEITC in lung cancer in smokers. The primary objective of this trial is determine the effect of PEITC on metabolism of the cigarette smoke procarcinogen 4-(methylnitrosoamino)-1-(3-pyridyl)-1-butanone (NNK) whereas secondary objectives include histopathological evaluation of lung lesions and analysis of cell cycle and apoptosis biomarkers in bronchial tissue. A phase I trial (NCT00005883) 
Isothiocyanates and angiogenesis

will determine the tolerability and toxicity of oral intake of SFN-enriched broccoli sprout extract in patients with invasive transitional cell carcinoma of the bladder (with secondary aims to study the effects on tumour angiogenesis, cell proliferation and apoptosis). Finally, a randomised, placebo-controlled phase II trial (NCT00843167) effect will assess the effects of broccoli sprout extract on markers of apoptosis and cell proliferation, and on inhibition of HDACs, in women newly diagnosed with ductal breast carcinoma in situ and/or atypical ductal hyperplasia. The results described here suggest that clinical evaluation of ITCs could be extended to (pre)malignancies associated with pronounced angiogenesis, such as renal cell carcinoma. Although normal dietary intake of ITCs is widely considered to be safe, the same may not be true of pharmacological doses and an important goal of these trials will be to assess safety. Indeed, widespread inhibition of multiple pathways, as may be expected for pleiotropic agents such as ITCs, may lead to significant toxicity. It will also be important to consider the potential for drug-drug interactions since induction of drug efflux pumps and phase I and II drug metabolising enzymes by ITCs may alter the metabolism and disposition of other pharmacological agents [78]. For example, even intake of $50 \mathrm{~g}$ of watercress has been shown to alter metabolism of acetaminophen [79].

\section{Conclusions}

The studies described in this review provide compelling evidence that, in addition to their well characterized effects on carcinogen activation and cell cycle and apoptosis, ITCs can exert anti-angiogenic activity in in vitro and in vivo models. However, it remains unclear to what extent these effects contribute to the potential chemopreventive activity of dietary intake of ITCs. The mechanisms by which ITCs modulate angiogenesis are likely to be multifactorial and complex, which presumably reflects the pleiotropic effects of these compounds. HIF is a major regulator of angiogenesis and its inhibition, perhaps predominantly via suppression of protein translation, is likely to play a central role in the anti-angiogenic effects of ITCs. However, angiogenesis is also controlled independently of HIF, and key roles have been ascribed to other transcription factors, including NF-kB, AP1 and MYC, and to 
tubulin, all of which can be modulated by ITCs. Further studies are required to understand molecular mechanisms by which ITCs exert their anti-angiogenic effects, and whether normal dietary intake or pharmacological administration of ITCs is sufficient to modulate these pathways in vivo.

\section{Acknowledgements}

Work on isothiocyantes in the authors' laboratories are supported by the Biochemical and Biophysical Sciences Reseach Council, the Kerkut Trust, Cancer Research UK, the Malaysian Government, the University of Southampton and the Watercress Alliance. These sponsors had no involvement in the preparation of this work.

\section{References}

[1] Cheung KL, Kong AN. Molecular targets of dietary phenethyl isothiocyanate and sulforaphane for cancer chemoprevention. AAPS J 2010;12:87-97.

[2] Juge N, Mithen RF, Traka M. Molecular basis for chemoprevention by sulforaphane: a comprehensive review. Cell Mol Life Sci 2007;64:1105-27.

[3] Hayes JD, Kelleher MO, Eggleston IM. The cancer chemopreventive actions of phytochemicals derived from glucosinolates. Eur J Nutr 2008;47 Suppl 2:73-88.

[4] Clarke JD, Dashwood RH, Ho E. Multi-targeted prevention of cancer by sulforaphane. Cancer Lett 2008;269:291-304.

[5] Zhang Y. Cancer-preventive isothiocyanates: measurement of human exposure and mechanism of action. Mutat Res 2004;555:173-90.

[6] Mennicke WH, Gorler K, Krumbiegel G, Lorenz D, Rittmann N. Studies on the metabolism and excretion of benzyl isothiocyanate in man. Xenobiotica 1988;18:441-7.

[7] Getahun SM, Chung FL. Conversion of glucosinolates to isothiocyanates in humans after ingestion of cooked watercress. Cancer Epidemiol Biomarkers Prev 1999;8:447-51.

[8] Shapiro TA, Fahey JW, Wade KL, Stephenson KK, Talalay P. Chemoprotective glucosinolates and isothiocyanates of broccoli sprouts: metabolism and excretion in humans. Cancer Epidemiol Biomarkers Prev 2001;10:501-8.

[9] Brennan P, Hsu CC, Moullan N, Szeszenia-Dabrowska N, Lissowska J, Zaridze $\mathrm{D}$, et al. Effect of cruciferous vegetables on lung cancer in patients stratified by genetic status: a mendelian randomisation approach. Lancet 2005;366:1558-60.

[10] Gasper AV, Al-Janobi A, Smith JA, Bacon JR, Fortun P, Atherton C, et al. Glutathione S-transferase M1 polymorphism and metabolism of sulforaphane 
from standard and high-glucosinolate broccoli. Am J Clin Nutr 2005;82:128391.

[11] Wang LI, Giovannucci EL, Hunter D, Neuberg D, Su L, Christiani DC. Dietary intake of Cruciferous vegetables, Glutathione S-transferase (GST) polymorphisms and lung cancer risk in a Caucasian population. Cancer Causes Control 2004;15:977-85.

[12] Zhang Y, Callaway EC. High cellular accumulation of sulphoraphane, a dietary anticarcinogen, is followed by rapid transporter-mediated export as a glutathione conjugate. Biochem J 2002;364:301-7.

[13] Zhang $Y$. Role of glutathione in the accumulation of anticarcinogenic isothiocyanates and their glutathione conjugates by murine hepatoma cells. Carcinogenesis 2000;21:1175-82.

[14] Trachootham D, Zhou Y, Zhang H, Demizu Y, Chen Z, Pelicano H, et al. Selective killing of oncogenically transformed cells through a ROS-mediated mechanism by beta-phenylethyl isothiocyanate. Cancer Cell 2006;10:241-52.

[15] Dashwood RH, Ho E. Dietary agents as histone deacetylase inhibitors: sulforaphane and structurally related isothiocyanates. Nutr Rev 2008;66 Suppl 1:S36-8.

[16] Mi L, Wang X, Govind S, Hood BL, Veenstra TD, Conrads TP, et al. The role of protein binding in induction of apoptosis by phenethyl isothiocyanate and sulforaphane in human non-small lung cancer cells. Cancer Res 2007;67:6409-16.

[17] Xu K, Thornalley PJ. Involvement of glutathione metabolism in the cytotoxicity of the phenethyl isothiocyanate and its cysteine conjugate to human leukaemia cells in vitro. Biochem Pharmacol 2001;61:165-77.

[18] Li W, Kong AN. Molecular mechanisms of Nrf2-mediated antioxidant response. Mol Carcinog 2009;48:91-104.

[19] Khor TO, Yu S, Kong AN. Dietary cancer chemopreventive agents - targeting inflammation and Nrf2 signaling pathway. Planta Med 2008;74:1540-7.

[20] Sharma RA, Harris AL, Dalgleish AG, Steward WP, O'Byrne KJ. Angiogenesis as a biomarker and target in cancer chemoprevention. Lancet Oncol 2001;2:726-32.

[21] Baeriswyl V, Christofori G. The angiogenic switch in carcinogenesis. Semin Cancer Biol 2009;19:329-37.

[22] Asakage M, Tsuno NH, Kitayama J, Tsuchiya T, Yoneyama S, Yamada J, et al. Sulforaphane induces inhibition of human umbilical vein endothelial cells proliferation by apoptosis. Angiogenesis 2006;9:83-91.

[23] Bertl E, Bartsch H, Gerhauser C. Inhibition of angiogenesis and endothelial cell functions are novel sulforaphane-mediated mechanisms in chemoprevention. Mol Cancer Ther 2006;5:575-85.

[24] Xiao D, Singh SV. Phenethyl isothiocyanate inhibits angiogenesis in vitro and ex vivo. Cancer Res 2007;67:2239-46.

[25] Thejass P, Kuttan G. Inhibition of endothelial cell differentiation and proinflammatory cytokine production during angiogenesis by allyl isothiocyanate and phenyl isothiocyanate. Integr Cancer Ther 2007;6:389-99.

[26] Jackson SJ, Singletary KW, Venema RC. Sulforaphane suppresses angiogenesis and disrupts endothelial mitotic progression and microtubule polymerization. Vascul Pharmacol 2007;46:77-84.

[27] Thejass P, Kuttan G. Allyl isothiocyanate (AITC) and phenyl isothiocyanate (PITC) inhibit tumour-specific angiogenesis by downregulating nitric oxide 
(NO) and tumour necrosis factor-alpha (TNF-alpha) production. Nitric Oxide 2007;16:247-57.

[28] Kallifatidis G, Rausch V, Baumann B, Apel A, Beckermann BM, Groth A, et al. Sulforaphane targets pancreatic tumour-initiating cells by NF-kappaB-induced antiapoptotic signalling. Gut 2009;58:949-63.

[29] Nakayama K. Cellular signal transduction of the hypoxia response. J Biochem 2009;146:757-765.

[30] Carroll VA, Ashcroft M. Targeting the molecular basis for tumour hypoxia. Expert Rev Mol Med 2005;7:1-16.

[31] Wang XH, Cavell BE, Syed Alwi SS, Packham G. Inhibition of hypoxia inducible factor by phenethyl isothiocyanate. Biochem Pharmacol 2009;78:261-72.

[32] Yao H, Wang H, Zhang Z, Jiang BH, Luo J, Shi X. Sulforaphane inhibited expression of hypoxia-inducible factor-1alpha in human tongue squamous cancer cells and prostate cancer cells. Int J Cancer 2008;123:1255-61.

[33] Hu J, Straub J, Xiao D, Singh SV, Yang HS, Sonenberg N, et al. Phenethyl isothiocyanate, a cancer chemopreventive constituent of cruciferous vegetables, inhibits cap-dependent translation by regulating the level and phosphorylation of 4E-BP1. Cancer Res 2007;67:3569-73.

[34] Kleijn M, Scheper GC, Voorma HO, Thomas AA. Regulation of translation initiation factors by signal transduction. Eur J Biochem 1998;253:531-44.

[35] De Benedetti A, Harris AL. elF4E expression in tumors: its possible role in progression of malignancies. Int J Biochem Cell Biol 1999;31:59-72.

[36] Toschi A, Lee E, Gadir N, Ohh M, Foster DA. Differential dependence of hypoxia-inducible factors 1 alpha and 2 alpha on mTORC1 and mTORC2. J Biol Chem 2008;283:34495-9.

[37] Mizukami Y, Kohgo Y, Chung DC. Hypoxia inducible factor-1 independent pathways in tumor angiogenesis. Clin Cancer Res 2007;13:5670-4.

[38] Mizukami Y, Jo WS, Duerr EM, Gala M, Li J, Zhang X, et al. Induction of interleukin-8 preserves the angiogenic response in HIF-1alpha-deficient colon cancer cells. Nat Med 2005;11:992-7.

[39] Wong ET, Tergaonkar V. Roles of NF-kappaB in health and disease: mechanisms and therapeutic potential. Clin Sci (Lond) 2009;116:451-65.

[40] Cummins EP, Berra E, Comerford KM, Ginouves A, Fitzgerald KT, Seeballuck $F$, et al. Prolyl hydroxylase-1 negatively regulates IkappaB kinase-beta, giving insight into hypoxia-induced NFkappaB activity. Proc Natl Acad Sci U S A 2006;103:18154-9.

[41] Heiss E, Herhaus C, Klimo K, Bartsch H, Gerhauser C. Nuclear factor kappa $B$ is a molecular target for sulforaphane-mediated anti-inflammatory mechanisms. J Biol Chem 2001;276:32008-15.

[42] Jeong WS, Kim IW, Hu R, Kong AN. Modulatory properties of various natural chemopreventive agents on the activation of NF-kappaB signaling pathway. Pharm Res 2004;21:661-70.

[43] Srivastava SK, Singh SV. Cell cycle arrest, apoptosis induction and inhibition of nuclear factor kappa B activation in anti-proliferative activity of benzyl isothiocyanate against human pancreatic cancer cells. Carcinogenesis 2004;25:1701-9.

[44] Xu C, Shen G, Chen C, Gelinas C, Kong AN. Suppression of NF-kappaB and NF-kappaB-regulated gene expression by sulforaphane and PEITC through 
Isothiocyanates and angiogenesis

IkappaBalpha, IKK pathway in human prostate cancer PC-3 cells. Oncogene 2005;24:4486-95.

[45] Shan Y, Wu K, Wang W, Wang S, Lin N, Zhao R, et al. Sulforaphane downregulates COX-2 expression by activating p38 and inhibiting NF-kappaBDNA-binding activity in human bladder T24 cells. Int J Oncol 2009;34:112934.

[46] Moon DO, Kim MO, Kang SH, Choi YH, Kim GY. Sulforaphane suppresses TNF-alpha-mediated activation of NF-kappaB and induces apoptosis through activation of reactive oxygen species-dependent caspase-3. Cancer Lett 2009;274:132-42.

[47] Na HK, Surh YJ. Transcriptional regulation via cysteine thiol modification: a novel molecular strategy for chemoprevention and cytoprotection. Mol Carcinog 2006;45:368-80.

[48] Fahey JW, Haristoy X, Dolan PM, Kensler TW, Scholtus I, Stephenson KK, et al. Sulforaphane inhibits extracellular, intracellular, and antibiotic-resistant strains of Helicobacter pylori and prevents benzo[a]pyrene-induced stomach tumors. Proc Natl Acad Sci U S A 2002;99:7610-5.

[49] Ramos-Gomez M, Kwak MK, Dolan PM, Itoh K, Yamamoto M, Talalay P, et al. Sensitivity to carcinogenesis is increased and chemoprotective efficacy of enzyme inducers is lost in nrf2 transcription factor-deficient mice. Proc Natl Acad Sci U S A 2001;98:3410-5.

[50] Xia YF, Ye BQ, Li YD, Wang JG, He XJ, Lin X, et al. Andrographolide attenuates inflammation by inhibition of NF-kappa B activation through covalent modification of reduced cysteine 62 of p50. J Immunol 2004;173:4207-17.

[51] Anand P, Kunnumakkara AB, Harikumar KB, Ahn KS, Badmaev V, Aggarwal $\mathrm{BB}$. Modification of cysteine residue in $\mathrm{p} 65$ subunit of nuclear factor-kappaB (NF-kappaB) by picroliv suppresses NF-kappaB-regulated gene products and potentiates apoptosis. Cancer Res 2008;68:8861-70.

[52] Byun MS, Choi J, Jue DM. Cysteine-179 of IkappaB kinase beta plays a critical role in enzyme activation by promoting phosphorylation of activation loop serines. Exp Mol Med 2006;38:546-52.

[53] Jobin C, Bradham CA, Russo MP, Juma B, Narula AS, Brenner DA, et al. Curcumin blocks cytokine-mediated NF-kappa B activation and proinflammatory gene expression by inhibiting inhibitory factor I-kappa B kinase activity. J Immunol 1999;163:3474-83.

[54] Pandey MK, Sandur SK, Sung B, Sethi G, Kunnumakkara AB, Aggarwal BB. Butein, a tetrahydroxychalcone, inhibits nuclear factor (NF)-kappaB and NFkappaB-regulated gene expression through direct inhibition of IkappaBalpha kinase beta on cysteine 179 residue. J Biol Chem 2007;282:17340-50.

[55] Lee DF, Kuo HP, Liu M, Chou CK, Xia W, Du Y, et al. KEAP1 E3 ligasemediated downregulation of NF-kappaB signaling by targeting IKKbeta. Mol Cell 2009;36:131-40.

[56] Hess J, Angel P, Schorpp-Kistner M. AP-1 subunits: quarrel and harmony among siblings. J Cell Sci 2004;117:5965-73.

[57] Jochum W, Passegue E, Wagner EF. AP-1 in mouse development and tumorigenesis. Oncogene $2001 ; 20: 2401-12$.

[58] Schmidt D, Textor B, Pein OT, Licht AH, Andrecht S, Sator-Schmitt M, et al. Critical role for NF-kappaB-induced JunB in VEGF regulation and tumor angiogenesis. EMBO J 2007;26:710-9. 
Isothiocyanates and angiogenesis

[59] Jeong WS, Kim IW, Hu R, Kong AN. Modulation of AP-1 by natural chemopreventive compounds in human colon HT-29 cancer cell line. Pharm Res 2004;21:649-60.

[60] Zhu M, Zhang Y, Cooper S, Sikorski E, Rohwer J, Bowden GT. Phase II enzyme inducer, sulforaphane, inhibits UVB-induced AP-1 activation in human keratinocytes by a novel mechanism. Mol Carcinog 2004;41:179-86.

[61] Dickinson SE, Melton TF, Olson ER, Zhang J, Saboda K, Bowden GT. Inhibition of activator protein-1 by sulforaphane involves interaction with cysteine in the cFos DNA-binding domain: implications for chemoprevention of UVB-induced skin cancer. Cancer Res 2009;69:7103-10.

[62] Li J, Yao S, Zhang Y. The role of C-Jun in the AP-1 activation induced by naturally occurring isothiocyanates. Food Chem Toxicol 2005;43:1373-80.

[63] Xu C, Shen G, Yuan X, Kim JH, Gopalkrishnan A, Keum YS, et al. ERK and JNK signaling pathways are involved in the regulation of activator protein 1 and cell death elicited by three isothiocyanates in human prostate cancer PC3 cells. Carcinogenesis 2006;27:437-45.

[64] Jackson SJ, Singletary KW. Sulforaphane inhibits human MCF-7 mammary cancer cell mitotic progression and tubulin polymerization. J Nutr 2004;134:2229-36.

[65] Smith TK, Lund EK, Parker ML, Clarke RG, Johnson IT. Allyl-isothiocyanate causes mitotic block, loss of cell adhesion and disrupted cytoskeletal structure in HT29 cells. Carcinogenesis 2004;25:1409-15.

[66] Mi L, Xiao Z, Hood BL, Dakshanamurthy S, Wang X, Govind S, et al. Covalent binding to tubulin by isothiocyanates. A mechanism of cell growth arrest and apoptosis. J Biol Chem 2008;283:22136-46.

[67] Mi L, Gan N, Cheema A, Dakshanamurthy S, Wang X, Yang DC, et al. Cancer preventive isothiocyanates induce selective degradation of cellular alpha- and beta-tubulins by proteasomes. J Biol Chem 2009;284:17039-51.

[68] Yin P, Kawamura T, He M, Vanaja DK, Young CY. Phenethyl isothiocyanate induces cell cycle arrest and reduction of alpha- and beta-tubulin isotypes in human prostate cancer cells. Cell Biol Int 2009;33:57-64.

[69] Escuin D, Kline ER, Giannakakou P. Both microtubule-stabilizing and microtubule-destabilizing drugs inhibit hypoxia-inducible factor-1alpha accumulation and activity by disrupting microtubule function. Cancer Res 2005;65:9021-8.

[70] Myzak MC, Ho E, Dashwood RH. Dietary agents as histone deacetylase inhibitors. Mol Carcinog 2006;45:443-6.

[71] Ellis L, Hammers H, Pili R. Targeting tumor angiogenesis with histone deacetylase inhibitors. Cancer Lett 2009;280:145-53.

[72] Ji Y, Morris ME. Determination of phenethyl isothiocyanate in human plasma and urine by ammonia derivatization and liquid chromatography-tandem mass spectrometry. Anal Biochem 2003;323:39-47.

[73] Syed Alwi SS, Cavell BE, Telang U, Morris ME, Parry BM, Packham G. In vivo modulation of 4E binding protein 1 (4E-BP1) phosphorylation by watercress: a pilot study. Br J Nutr 2010:1-9.

[74] Al Janobi AA, Mithen RF, Gasper AV, Shaw PN, Middleton RJ, Ortori CA, et al. Quantitative measurement of sulforaphane, iberin and their mercapturic acid pathway metabolites in human plasma and urine using liquid chromatography-tandem electrospray ionisation mass spectrometry. J Chromatogr B Analyt Technol Biomed Life Sci 2006;844:223-34. 
[75] Gill Cl, Haldar S, Boyd LA, Bennett R, Whiteford J, Butler M, et al. Watercress supplementation in diet reduces lymphocyte DNA damage and alters blood antioxidant status in healthy adults. Am J Clin Nutr 2007;85:504-10.

[76] Myzak MC, Tong P, Dashwood WM, Dashwood RH, Ho E. Sulforaphane retards the growth of human PC-3 xenografts and inhibits HDAC activity in human subjects. Exp Biol Med (Maywood) 2007;232:227-34.

[77] Trachootham D, Zhang H, Zhang W, Feng L, Du M, Zhou Y, et al. Effective elimination of fludarabine-resistant CLL cells by PEITC through a redoxmediated mechanism. Blood 2008;112:1912-22.

[78] Fimognari C, Lenzi M, Hrelia P. Interaction of the isothiocyanate sulforaphane with drug disposition and metabolism: pharmacological and toxicological implications. Curr Drug Metab 2008;9:668-78.

[79] Chen L, Mohr SN, Yang CS. Decrease of plasma and urinary oxidative metabolites of acetaminophen after consumption of watercress by human volunteers. Clin Pharmacol Ther 1996;60:651-60.

[80] Moreno RL, Kent UM, Hodge K, Hollenberg PF. Inactivation of cytochrome P450 2E1 by benzyl isothiocyanate. Chem Res Toxicol 1999;12:582-7.

[81] Conaway CC, Jiao D, Chung FL. Inhibition of rat liver cytochrome P450 isozymes by isothiocyanates and their conjugates: a structure-activity relationship study. Carcinogenesis 1996;17:2423-7.

[82] Smith TJ, Guo Z, Guengerich FP, Yang CS. Metabolism of 4(methylnitrosamino)-1-(3-pyridyl)-1-butanone (NNK) by human cytochrome P450 1A2 and its inhibition by phenethyl isothiocyanate. Carcinogenesis 1996;17:809-13.

[83] Ishizaki H, Brady JF, Ning SM, Yang CS. Effect of phenethyl isothiocyanate on microsomal $\mathrm{N}$-nitrosodimethylamine metabolism and other monooxygenase activities. Xenobiotica 1990;20:255-64.

[84] Maheo K, Morel F, Langouet S, Kramer H, Le Ferrec E, Ketterer B, et al. Inhibition of cytochromes P-450 and induction of glutathione S-transferases by sulforaphane in primary human and rat hepatocytes. Cancer Res 1997;57:3649-52.

[85] Xu C, Yuan X, Pan Z, Shen G, Kim JH, Yu S, et al. Mechanism of action of isothiocyanates: the induction of ARE-regulated genes is associated with activation of ERK and JNK and the phosphorylation and nuclear translocation of Nrf2. Mol Cancer Ther 2006;5:1918-26.

[86] Jeong WS, Keum YS, Chen C, Jain MR, Shen G, Kim JH, et al. Differential expression and stability of endogenous nuclear factor E2-related factor 2 (Nrf2) by natural chemopreventive compounds in HepG2 human hepatoma cells. J Biochem Mol Biol 2005;38:167-76.

[87] Keum YS, Owuor ED, Kim BR, Hu R, Kong AN. Involvement of Nrf2 and JNK1 in the activation of antioxidant responsive element (ARE) by chemopreventive agent phenethyl isothiocyanate (PEITC). Pharm Res 2003;20:1351-6.

[88] Zhang Y, Tang L, Gonzalez V. Selected isothiocyanates rapidly induce growth inhibition of cancer cells. Mol Cancer Ther 2003;2:1045-52.

[89] Miyoshi N, Uchida K, Osawa T, Nakamura Y. A link between benzyl isothiocyanate-induced cell cycle arrest and apoptosis: involvement of mitogen-activated protein kinases in the Bcl-2 phosphorylation. Cancer Res 2004;64:2134-42. 
[90] Pham NA, Jacobberger JW, Schimmer AD, Cao P, Gronda M, Hedley DW. The dietary isothiocyanate sulforaphane targets pathways of apoptosis, cell cycle arrest, and oxidative stress in human pancreatic cancer cells and inhibits tumor growth in severe combined immunodeficient mice. Mol Cancer Ther 2004;3:1239-48.

[91] Gamet-Payrastre L, Li P, Lumeau S, Cassar G, Dupont MA, Chevolleau S, et al. Sulforaphane, a naturally occurring isothiocyanate, induces cell cycle arrest and apoptosis in HT29 human colon cancer cells. Cancer Res 2000;60:1426-33.

[92] Xiao D, Johnson CS, Trump DL, Singh SV. Proteasome-mediated degradation of cell division cycle 25C and cyclin-dependent kinase 1 in phenethyl isothiocyanate-induced G2-M-phase cell cycle arrest in PC-3 human prostate cancer cells. Mol Cancer Ther 2004;3:567-75.

[93] Xu K, Thornalley PJ. Studies on the mechanism of the inhibition of human leukaemia cell growth by dietary isothiocyanates and their cysteine adducts in vitro. Biochem Pharmacol 2000;60:221-31.

[94] Yu R, Mandlekar S, Harvey KJ, Ucker DS, Kong AN. Chemopreventive isothiocyanates induce apoptosis and caspase-3-like protease activity. Cancer Res 1998;58:402-8.

[95] Xiao D, Zeng Y, Choi S, Lew KL, Nelson JB, Singh SV. Caspase-dependent apoptosis induction by phenethyl isothiocyanate, a cruciferous vegetablederived cancer chemopreventive agent, is mediated by Bak and Bax. Clin Cancer Res 2005;11:2670-9.

[96] Kuang YF, Chen YH. Induction of apoptosis in a non-small cell human lung cancer cell line by isothiocyanates is associated with P53 and P21. Food Chem Toxicol 2004;42:1711-8.

[97] Nakamura Y, Kawakami M, Yoshihiro A, Miyoshi N, Ohigashi H, Kawai K, et al. Involvement of the mitochondrial death pathway in chemopreventive benzyl isothiocyanate-induced apoptosis. J Biol Chem 2002;277:8492-9.

[98] Hwang ES, Lee HJ. Allyl isothiocyanate and its $\mathrm{N}$-acetylcysteine conjugate suppress metastasis via inhibition of invasion, migration, and matrix metalloproteinase-2/-9 activities in SK-Hep 1 human hepatoma cells. Exp Biol Med (Maywood) 2006;231:421-30.

[99] Hwang ES, Lee HJ. Phenylethyl isothiocyanate and its N-acetylcysteine conjugate suppress the metastasis of SK-Hep1 human hepatoma cells. J Nutr Biochem 2006;17:837-46.

[100] Thejass P, Kuttan G. Antimetastatic activity of Sulforaphane. Life Sci 2006;78:3043-50.

[101] Heiss E, Gerhauser C. Time-dependent modulation of thioredoxin reductase activity might contribute to sulforaphane-mediated inhibition of NF-kappaB binding to DNA. Antioxid Redox Signal 2005;7:1601-11. 
Isothiocyanates and angiogenesis

\section{Figure legends}

Fig. 1. Isothiocyanates. Myrosinase-mediated generation of ITCs (R-NCS) from glucosinolate precursors (top) and structures of representative dietary ITCs (bottom).

Fig. 2. Intracellular accumulation of ITCs. Following their initial diffusion into cells (1), ITCs are rapidly conjugated to glutathione (GSH) via the action of glutathione-Stransferases (GST) (2). The GSH conjugates are exported from the cells via efflux pumps (3). Extracellular hydrolysis of the GSH conjugate (4) gives rise to the free ITC which is able to re-enter the cell. The net effect of this cycle is the rapid (1-3 hr) and profound (100-200 fold) accumulation of ITC and the concomitant depletion of GSH. Once GSH levels are reduced, ITCs are able to conjugate to intracellular protein cysteinyl thiols.

Fig. 3. Regulation of HIF1 activity. In normoxia, hypoxia-inducible factor (HIF)-1 $\alpha$ is hydroxylated by proline hydroxylases (PHD) in the presence of $\mathrm{O}_{2}$. Hydroxylated HIF-1 $\alpha$ is recognised by VHL (von Hippel-Lindau protein) resulting in polyubiquitination and proteasomal degradation. In response to hypoxia, proline hydroxylation is inhibited. VHL is no longer able to bind and target HIF-1 $\alpha$ for proteasomal degradation and HIF-1 $\alpha$ accumulates and translocates to the nucleus. HIF-1 $\alpha$ dimerises with HIF-1 $\beta$, binds to hypoxia-response elements (HREs) within the promoters of target genes and recruits transcriptional co-activators such as p300/CBP for full transcriptional activity. CBP, CREB-binding protein; Ub, ubiquitin. Adapted from Ref. [30].

Fig. 4. HIF-dependent and independent regulation of angiogenesis. Activation of HIF by inhibition of prolyl hydroxylase activity in hypoxic conditions plays a key role in induction of pro-angiogenic factors, including interleukin 8 (IL8), angiopoietin 2 (Ang2) and vascular endothelial growth factor (VEGF). HIF1 activity is also highly dependent on efficient translation of the HIF1 $\alpha$ RNA. However, NF-kB, AP1 and MYC also play key HIF-independent roles via induction of pro-angiogenic factors and repression of anti-angiogenic factors (e.g., thrombospondin-1, Tsp1). RAS can be activated by hypoxia and is a master regulator of these HIF-independent pathways. 
Isothiocyanates and angiogenesis

HIF depletion leads to enhanced production of reactive species, leading to activation of NF-kB and induction of IL8. Potential targets for the anti-angiogenic effects of ITCs are shown in boxes along with specific ITCs that have been shown to modulate these targets - see Table 2 and text for details. Solid and dashed lines indicate positive and negative regulation, respectively and in some cases this involves intermediate regulators which are not shown. Adapted from Ref. [37]. 
Table 1. Potential mechanisms contributing to anti-cancer effects of ITCs.

${ }^{a}$ Typical effective concentrations. Note that differences in assay design preclude direct comparison between studies.

In the interests of space, only selected references provided.

\begin{tabular}{|c|c|c|}
\hline $\begin{array}{l}\text { Biological } \\
\text { response }\end{array}$ & Effect & Conc $^{a}$ \\
\hline $\begin{array}{l}\text { Regulation of } \\
\text { P450 enzymes }\end{array}$ & $\begin{array}{l}\text { ITCs inhibit or downregulate various } \\
\text { cytochrome P450 enzymes, important for } \\
\text { activation of chemical carcinogens }\end{array}$ & $\begin{array}{l}13 \mu \mathrm{M} \text { (BITC) [80] } \\
1.8 \mu \mathrm{M} \text { (PEITC) [81] } \\
180 \mathrm{nM}, 340 \mathrm{nM} \\
\text { (PEITC) [82] } \\
1 \mu \mathrm{M} \text { (PEITC) [83] } \\
10 \mu \mathrm{M} \text { (SFN) [84] }\end{array}$ \\
\hline $\begin{array}{l}\text { Induction of } \\
\text { antioxidant } \\
\text { gene } \\
\text { expression }\end{array}$ & $\begin{array}{l}\text { ITCs increase activity of Nrf2 a key } \\
\text { transcription factor involved in induction of } \\
\text { oxidant/electrophile response genes and } \\
\text { mediators of chemopreventive activity }\end{array}$ & $\begin{array}{l}7.5 \mu \mathrm{M} \text { (PEITC) [85] } \\
25 \mu \mathrm{M} \text { (SFN, AITC) } \\
{[86]} \\
0.5 \mu \mathrm{M} \text { (PEITC) [87] }\end{array}$ \\
\hline $\begin{array}{l}\text { Cell cycle } \\
\text { arrest }\end{array}$ & $\begin{array}{l}\text { Inhibition of cell cycle progression has } \\
\text { been observed in a wide variety of cell } \\
\text { lines derived from both solid and } \\
\text { haematological malignancies. Arrest in } \mathrm{G}_{1} \text {, } \\
\mathrm{S} \text { or } \mathrm{G}_{2} / \mathrm{M} \text { phases of the cell cycle has } \\
\text { been described. }\end{array}$ & $\begin{array}{l}10 \mu \mathrm{M} \text { (AITC), } 10 \mu \mathrm{M} \\
(\mathrm{BITC}) \text { [88] } \\
2.5 \mu \mathrm{M} \text { (BITC) [89] } \\
10 \mu \mathrm{M} \text { (SFN) [90] } \\
12 \mu \mathrm{M} \text { (AITC) [65] } \\
15 \mu \mathrm{M} \text { (SFN) [91] } \\
5 \mu \mathrm{M} \text { (PEITC) [92] } \\
5 \mu \mathrm{M} \text { (BITC) [43] }\end{array}$ \\
\hline $\begin{array}{l}\text { Induction of } \\
\text { apoptosis }\end{array}$ & $\begin{array}{l}\text { Induction of both the intrinsic and extrinsic } \\
\text { apoptosis pathways has been observed in } \\
\text { a wide variety of cell lines derived from } \\
\text { both solid and haematological } \\
\text { malignancies. }\end{array}$ & $\begin{array}{l}5 \mu \mathrm{M} \text { (PEITC) [93] } \\
10 \mu \mathrm{M} \text { (PEITC) [94] } \\
5 \mu \mathrm{M} \text { (SFN) [90] } \\
15 \mu \mathrm{M} \text { (SFN) [91] } \\
5 \mu \mathrm{M} \text { (BITC) [43] } \\
10 \mu \mathrm{M} \text { (PEITC) [95] }\end{array}$ \\
\hline Induction of & Appears to require higher concentrations & $25 \mu \mathrm{M}$ (PEITC/BITC) \\
\hline
\end{tabular}




\begin{tabular}{|l|l|l|}
\hline necrosis & than induction of apoptosis & $\begin{array}{l}\text { [96] } \\
50 \mu \mathrm{m} \text { (BITC) [97] }\end{array}$ \\
\hline Metastasis & $\begin{array}{l}\text { ITCs inhibit cell adhesion, invasion and } \\
\text { migration in vitro, and metastasis in vivo }\end{array}$ & $\begin{array}{l}5 \mu \mathrm{M} \text { (AITC) [98] } \\
5 \mu \mathrm{MEITC}) \text { [99] }\end{array}$ \\
& & $\begin{array}{l}2 \mu \mathrm{M} \text { (PEITC) [24] } \\
2 \mu \mathrm{g} / \mathrm{ml} \text { (SFN) [100] }\end{array}$ \\
\hline Inhibition of & $\begin{array}{l}\text { ITCs inhibit angiogenesis in in vitro and in } \\
\text { vivo models }\end{array}$ & $\begin{array}{l}5 \mu \mathrm{M} \text { (PEITC) [24] } \\
5 \mathrm{ml} \text { (AITC) [27] }\end{array}$ \\
& & $0.1-1 \mu \mathrm{M}$ (SFN) [23] \\
& & \\
\hline
\end{tabular}


Table 2. Summary of in vitro effects of ITCs on potential molecular targets mediating anti-angiogenic effects.

${ }^{a}$ effective concentrations. Note that differences in assay design preclude direct comparison between studies.

\begin{tabular}{|c|c|c|c|}
\hline Target & Effect & $\begin{array}{l}\text { Conc } \\
(\mu \mathrm{M})^{\mathrm{a}}\end{array}$ & Refs \\
\hline \multirow[t]{3}{*}{ HIF } & $\begin{array}{l}\text { SFN decreased HIF1 } \alpha \text { RNA levels in HMEC- } \\
1 \text { cells. }\end{array}$ & 6.25 & \\
\hline & $\begin{array}{l}\text { PEITC inhibited HIF transcriptional activity in } \\
\text { MCF7 cells. Associated with reduced HIF1 } \alpha \\
\text { protein expression. }\end{array}$ & 3.25 & [31] \\
\hline & $\begin{array}{l}\text { SFN reduced HIF1 } \alpha \text { protein expression in } \\
\text { Tca8113 and DU145 cells }\end{array}$ & $5-10$ & {$[32]$} \\
\hline MYC & $\begin{array}{l}\text { SFN decreased MYC RNA levels in HMEC-1 } \\
\text { cells. }\end{array}$ & 1.56 & {$[23]$} \\
\hline \multirow[t]{5}{*}{$\mathrm{NF}-\kappa \mathrm{B}$} & 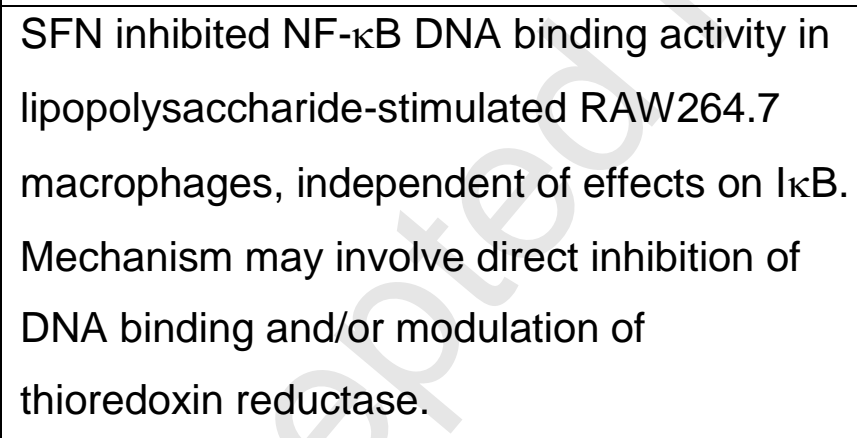 & 10 & $\begin{array}{l}{[41]} \\
{[101]}\end{array}$ \\
\hline & $\begin{array}{l}\text { BITC inhibited NF- } \kappa B \text { DNA binding activity in } \\
\text { Bx-PC3 cells, associated with reduced } I_{\kappa} B \alpha \\
\text { phosphorylation. }\end{array}$ & 20 & {$[43]$} \\
\hline & $\begin{array}{l}\text { SFN inhibited NF-kB DNA binding activity in } \\
\text { human pancreatic adenocarcinoma cells. }\end{array}$ & 10 & [28] \\
\hline & $\begin{array}{l}\text { PEITC/SFN inhibited NF- } \kappa B \text { transcriptional } \\
\text { activity in PC-3 cells. Associated with } \\
\text { decreased phosphorylation of IKK } \alpha \text { and } \\
\text { IKK } \beta \text {. }\end{array}$ & $\begin{array}{l}5 \text { (PEITC) } \\
\text { and } 20 \\
\text { (SFN) }\end{array}$ & [44] \\
\hline & PEITC, SFN, AITC inhibited LPS-induced & 10 & [42] \\
\hline
\end{tabular}




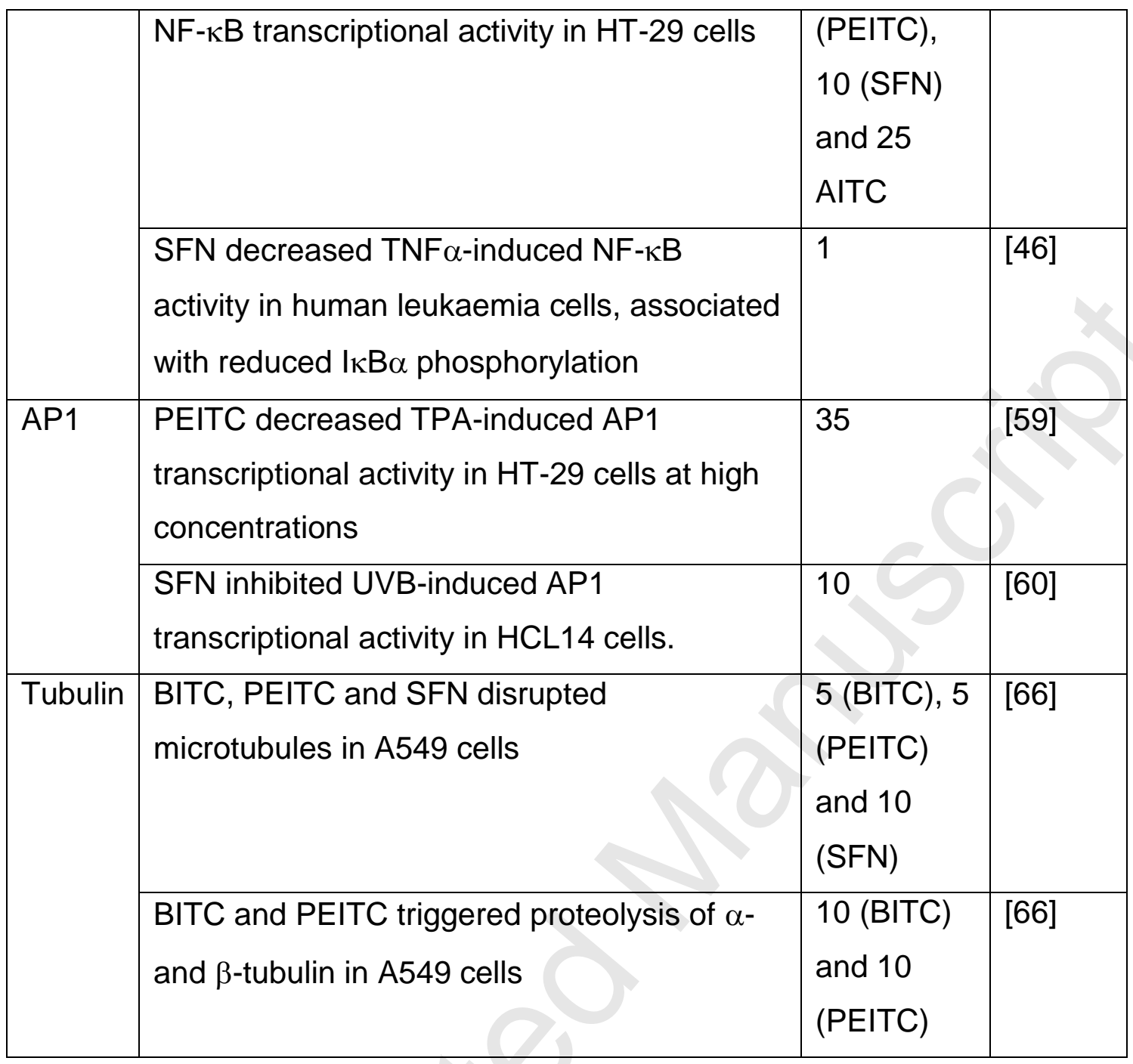


<smiles>[R]/C(=N/S(=O)(=O)[S-])SC(O)C(O)C(O)C(O)CO</smiles><smiles>[S]NCCc1ccccc1</smiles>

phenethyl isothiocyanate (PEITC)<smiles>CS(=O)CCCC[As]</smiles>
sulforaphane (SFN)

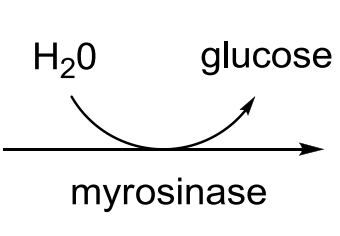<smiles>[R]/C([S-])=N/S(=O)(=O)[S-]</smiles><smiles>[R]N=C=S</smiles>

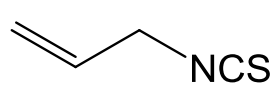

allyl isothiocyanate (AITC)<smiles>S=[As]Cc1ccccc1</smiles>

benzyl isothiocyanate (BITC) 
<smiles>[R]NC(=S)SCC(NC(=O)CCC(N)C(=O)O)C(=O)NCC(=O)O</smiles><smiles>[R]NC(=S)SCC(NC(=O)CCC(N)C(=O)O)C(=O)NCC(=O)O</smiles><smiles>[SiH3]</smiles>
GSH<smiles>[R]N=C=S</smiles>

(4)

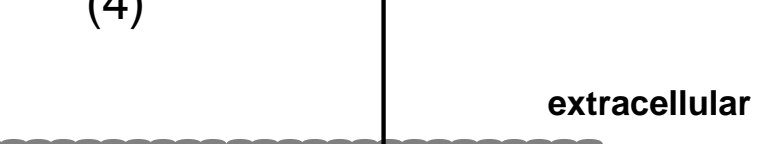<smiles>C#CC(C)(C)C(C)(Br)Br</smiles>

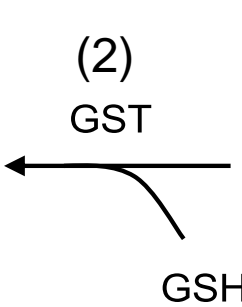

(5)<smiles>[R]N=C=CS</smiles><smiles>CCCC(=O)C(CS)NC</smiles><smiles>[R]NC(=S)SCC(NC(C)C)C1CCC1=O</smiles>

protein thiocarbamoylation 
Normoxia

Figure 3 (B\&W)

HIF-1 $\alpha$

HIF-1 $\alpha$

$\downarrow \mathrm{PH}$

HIF-1 $\alpha$

$\mathrm{OHOH}$

VHL

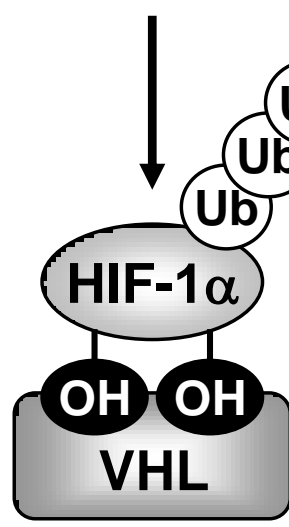

HIF-1 $\alpha$

HIF-1 $\alpha$

HIF-1 $\alpha$

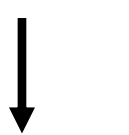

(HIF-1a)

HIF-1 $\alpha$

Ub

(U)

nuclear import

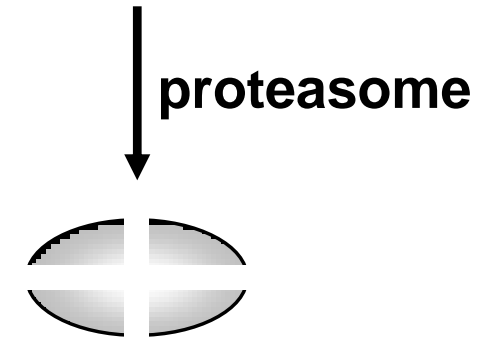

proteolysis

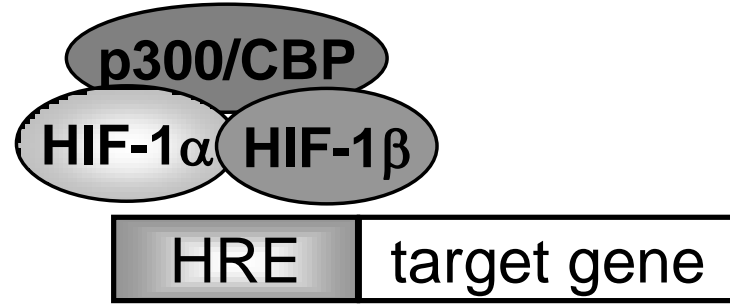

1. Angiogenesis

2. Apoptosis

3. $\mathrm{pH}$ regulation

4. Proteolysis

5. Glucose metabolism

6. Cell proliferation/survival

7. Erythropoiesis 
Normoxia

HIF-1 $\alpha$ VHL
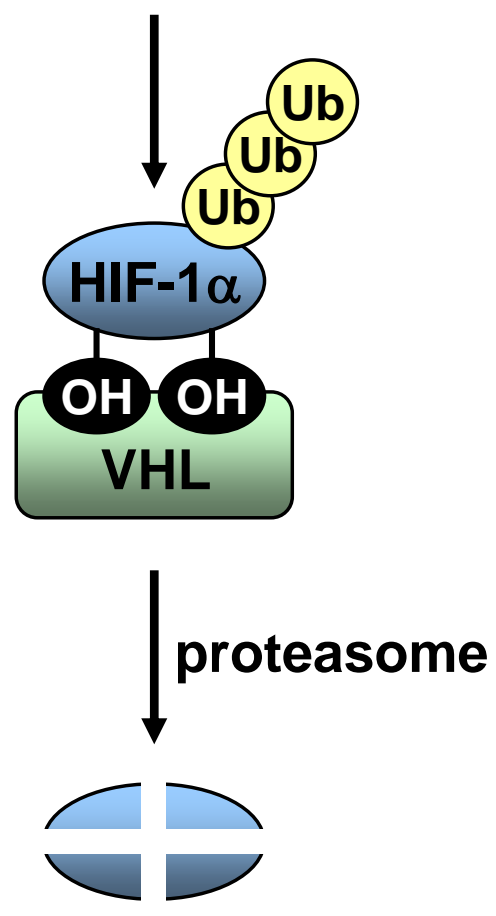

proteolysis
- Hypoxia

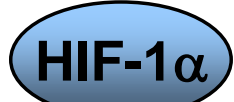

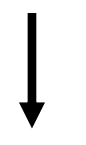

HIF-1 $\alpha$

HIF-1 $\alpha$

HIF-1 $\alpha$

HIF-1 $\alpha$ nuclear import

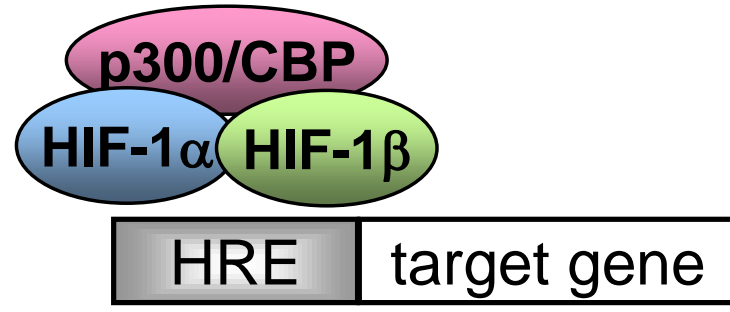

1. Angiogenesis

2. Apoptosis

3. $\mathrm{pH}$ regulation

4. Proteolysis

5. Glucose metabolism

6. Cell proliferation/survival

7. Erythropoiesis 


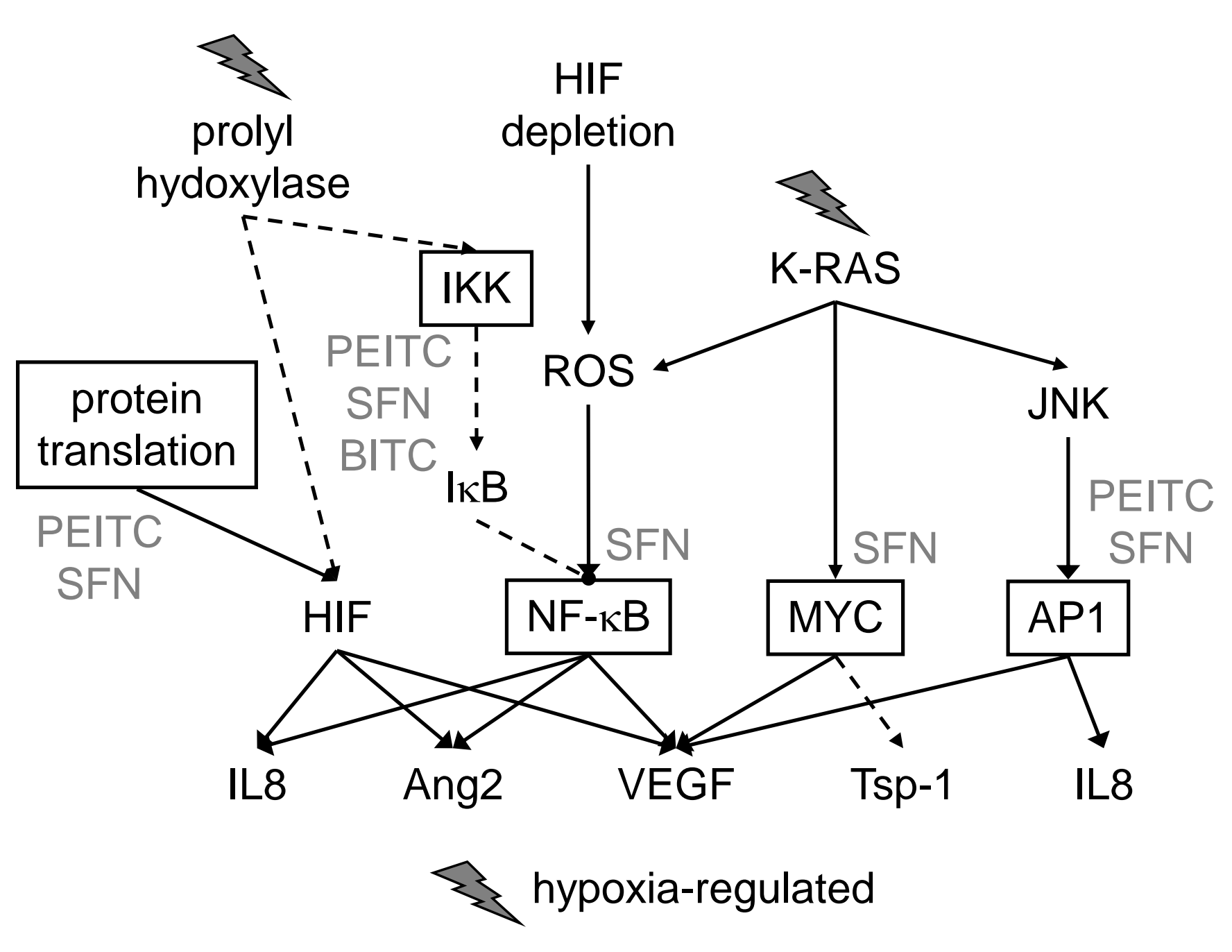

Figure 4 (B\&W) (B\&W) 
Figure 4 (Colour
on-line only) on-line only)

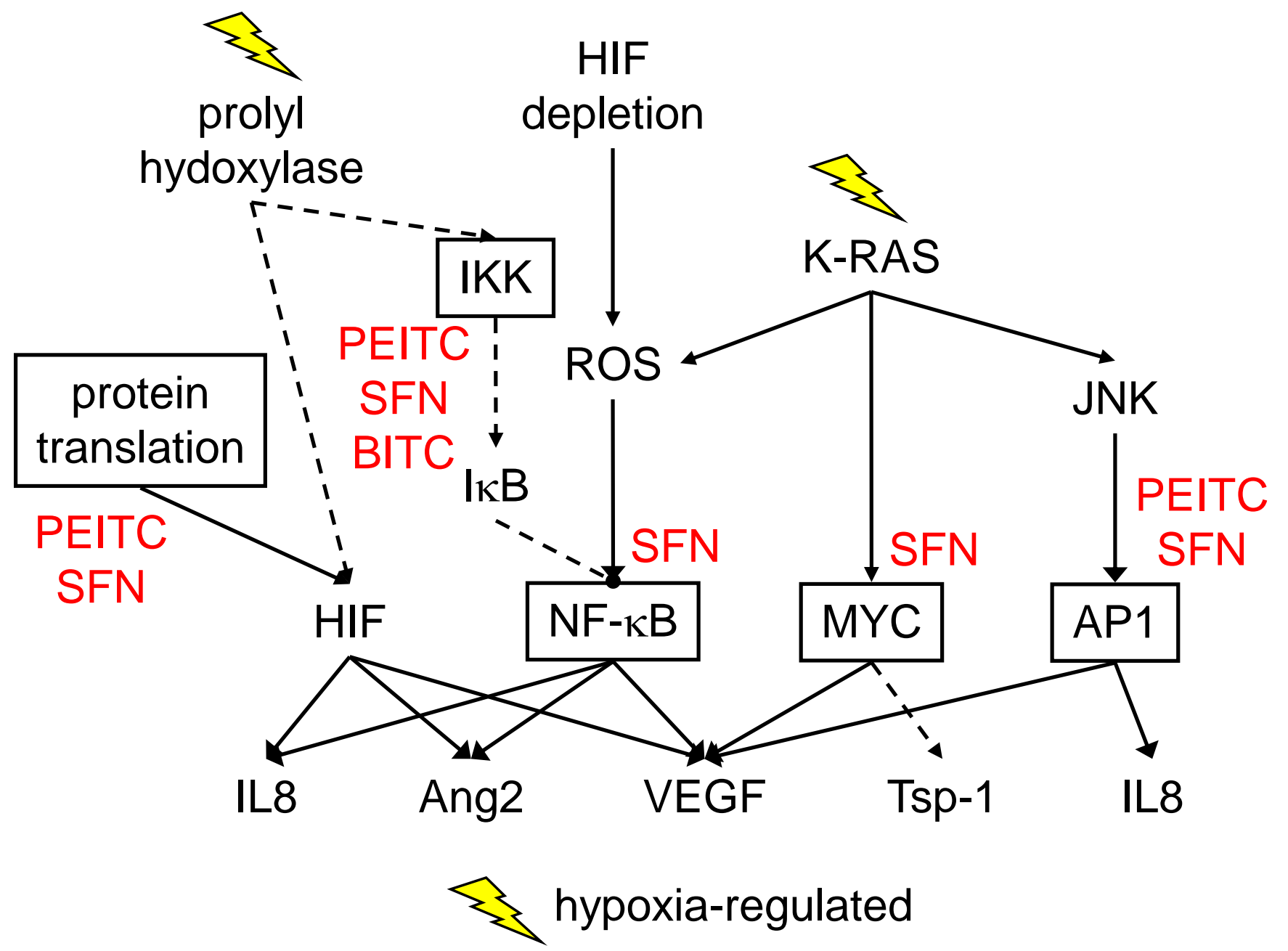

hypoxia-regulated

\section{depletion \\ HIF}

hydoxylase

-RAS
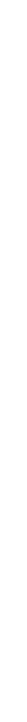


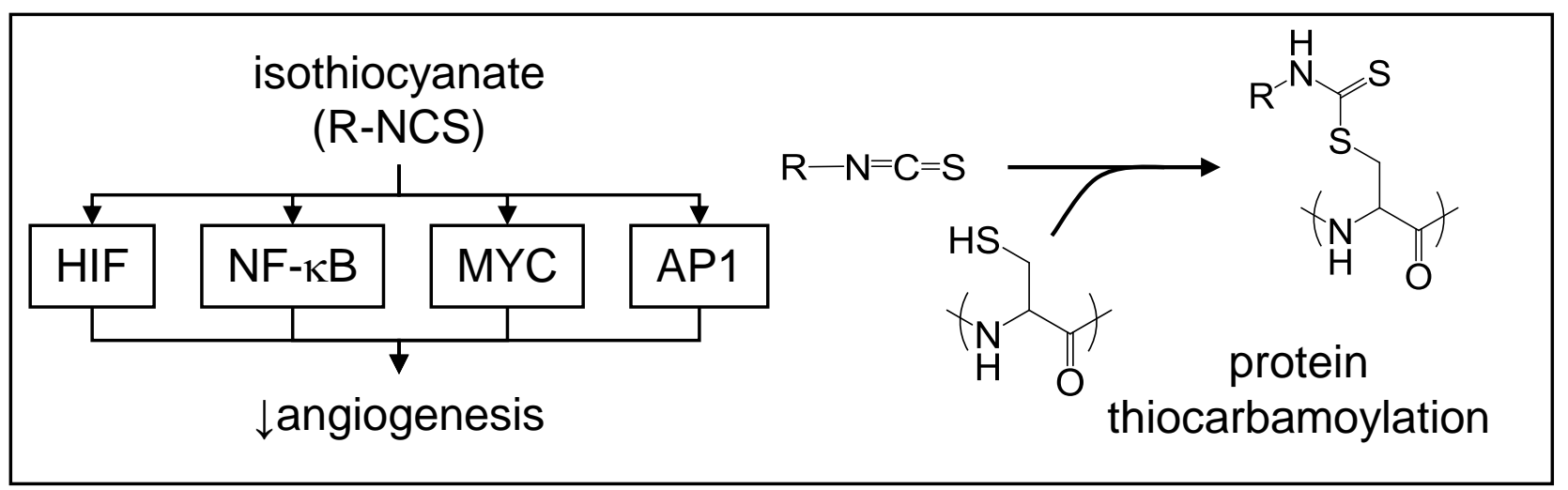

